\title{
Live Shopping dalam Industri Komunikasi Digital melalui Instagram
}

\author{
Vinia Fransiska, Sinta Paramita \\ viniafransiska@gmail.com, sintap@fikom.untar.ac.id \\ Fakultas Ilmu Komunikasi Universitas Tarumanagara
}

\begin{abstract}
Live shopping is an online shopping activity that is done directly and within a certain duration. This research discusses the live shopping process in the digital communication industry.. The theory used is the theory of marketing communication, social media, Instagram, and digital communication. This study discusses the phenomenon of live shopping activity in the digital communications industry. The method used is a case study with a qualitative approach and using the techniques of interview, observation, and documentation. The results of this study can be seen that the live shopping activity that uses social media to utilize the features of Instagram namely Stories. The birth of live shopping is based on the phenomenon that has been formed over a long time, namely 'jastip'. Goods sold in the live shopping activity are also more diverse than shop online as usual. It also offers more interactive shopping activities and fun so that buyers feel the thrill of shopping directly on the spot and the limited duration so that the buyers will be encouraged with time. Before live shopping, sellers will promote it by using Instagram Ads or endorsement to influencers. It can be concluded that the live shopping process starts with 3 main steps, promotion, interaction, and transaction.
\end{abstract}

Keywords: digital communication, instagram, live shopping, online shopping, social media

\begin{abstract}
Abstrak
Live shopping merupakan suatu kegiatan berbelanja secara online yang dilakukan secara langsung dan dalam durasi tertentu saja. Penelitian ini membahas tentang proses live shopping dalam industri komunikasi digital. Teori yang digunakan adalah teori komunikasi pemasaran, media sosial, Instagram, dan komunikasi digital. Metode yang digunakan adalah studi kasus dengan pendekatan kualitatif dan menggunakan teknik wawancara, observasi, serta dokumentasi. Hasil penelitian ini dapat diketahui bahwa kegiatan live shopping yang menggunakan media sosial Instagram ini memanfaatkan fitur Instagram yaitu Instagram Stories. Lahirnya live shopping didasari oleh fenomena yang sudah terbentuk lebih lama yaitu jasa titip atau jastip. Barang yang dijual dalam kegiatan live shopping juga lebih beragam dibandingkan berbelanja online seperti biasa. Kegiatan ini juga menawarkan kegiatan belanja yang lebih interaktif dan menyenangkan sehingga pembeli merasakan sensasi berbelanja langsung di tempat dan durasi waktu yang terbatas sehingga pembeli akan berpacu dengan waktu. Sebelum melakukan kegiatan live shopping, penjual terlebih dahulu akan memasarkannya dengan memanfaatkan fitur Instagram ads atau endorsement kepada influencer. Untuk itu dapat disimpulkan bahwa proses live shopping dimulai dari 3 langkah utama yaitu promosi, interaksi, dan terakhir transaksi.
\end{abstract}

Kata Kunci: belanja online, instagram, komunikasi digital, live shopping, media mosial

\section{Pendahuluan}

Keinginan manusia untuk mengakses informasi telah menjadi salah satu kebutuhan primer dari setiap orang. Hal ini disebabkan karena adanya informasi, 
hiburan, pendidikan, dan pengetahuan yang berasal dari seluruh belahan dunia dan tidak dapat diperoleh melalui media konvensional. Pesatnya perkembangan teknologi dan informasi serta semakin canggihnya perangkat-perangkat yang diproduksi oleh industri seperti menghadirkan "dunia dalam genggaman" (Rosliana \& Loisa, 2019)

Pertumbuhan internet telah mengalami kemajuan yang cukup pesat khususnya di Indonesia. Seiring dengan kemajuan ini, tingkat konsumerisme masyarakat juga ikut meningkat. Dengan hadirnya internet, masyarakat semakin mudah untuk berbelanja khususnya secara online daripada berbelanja secara konvensional. Seperti yang publikasi oleh www.cncbindonesia.com Berbelanja secara online dinilai lebih efisien dan lebih hemat secara materil maupun tenaga. Menurut Data Bank Indonesia (BI), transaksi toko online (e-commerce) di Indonesia sepanjang tahun 2018 lalu mencapai Rp 77.766 triliun. Angka ini meroket $151 \%$ dibandingkan tahun sebelumnya yang mencapai Rp 30.924 triliun. Dari data tersebut, tercatat kategori produk gadget \& accessories menyumbang paling banyak dengan nilai $\mathrm{Rp} 16.823$ triliun, dari tahun sebelumnya Rp 8.018 triliun. Dari data tersebut dapat disimpulkan bahwa transaksi pembelanjaan secara online bertumbuh secara pesat setiap tahunnya.

Lembaga riset asal Inggris, Merchant Machine, merilis daftar sepuluh negara dengan pertumbuhan e-commerce tercepat di dunia. Dalam daftar tersebut, Indonesia memimpin dengan tingkat pertumbuhan $78 \%$ pada tahun 2018. Jumlah pengguna internet Indonesia yang mencapai lebih dari 100 juta pengguna menjadi salah satu pendorong pertumbuhan e-commerce di Indonesia dalam www.databoks.katadata.co.id. Selain melalui e-commerce, transaksi belanja secara online di Indonesia juga memanfaatkan sosial media. Salah satu sosial media yang paling marak digunakan untuk berbelanja online adalah Instagram. Melalui Instagram, para penjual dapat dengan mudah memasarkan produk maupun jasa mereka melalui feeds ataupun story di Instagram. Selain itu penggunaan hashtag dalam setiap unggahan yang mereka unggah di Instagram juga memudahkan pencarian kepada para calon pembeli. Instagram merupakan salah satu media sosial yang memiliki beragam fitur yang canggih dan menarik. Kecanggihan tersebut dimanfaatkan hampir seluruh kalangan (Kulsia \& Paramita, 2018).

Semakin maraknya transaksi belanja online khususnya melalui Instagram telah memunculkan tren fenomena baru yang dinamakan live shopping. Kegiatan live shopping ini sedikit berbeda dengan belanja online biasanya. Dalam hal ini, penjual akan menghadirkan suasana belanja secara tidak langsung di depan mata calon pembeli. Hal ini dapat dilakukan dengan berbagai cara misalnya dengan live streaming atau penjual dapat mengunggah konten berjualan melalui fitur Instagram Story yang memungkinkan calon pembeli untuk langsung berinteraksi dengan penjual.

Melalui kegiatan live shopping, calon pembeli memiliki waktu yang terbatas dalam membeli produk yang dijual. Dikarenakan kegiatan tersebut dilaksanakan secara live, sehingga penjual tidak dapat menunggu di satu toko atau tempat dalam waktu yang lama karena penjual harus segera bergegas ke toko lainnya. Hal inilah yang membuat kegiatan live shopping berbeda yaitu lebih aktif daripada belanja online biasanya.

Salah satu kunci keberhasilan dalam transaksi berbelanja adalah komunikasi. Menurut David K. Berlo komunikasi merupakan instrumen dari interaksi sosial yang digunakan untuk mengetahui dan memprediksi sikap orang lain, serta untuk mengetahui keberadaan diri sendiri dalam menciptakan keseimbangan di tengah tengah masyarakat (Cangara, 2018,). Di era digital sekarang ini, komunikasi terus 
berkembang menyesuaikan perkembangan yang ada. Dalam kegiatan live shopping yang sedang marak, tentunya berpengaruh dalam industri komunikasi digital saat ini.

Berdasarkan realitas dan latar belakang yang telah ditulis diatas, penulis ingin mengetahui bagaimana live shopping dalam komunikasi industri digital khususnya melalui sosial media Instagram yang akan penulis tuangkan dalam penelitian berjudul "Live Shopping dalam Industri Komunikasi Digital melalui Instagram".

\section{Metode Penelitian}

Penelitian ini menggunakan pendekatan penelitian kualitatif dengan menggunakan metode studi kasus untuk mempelajari lebih lanjut mengenai proses dalam penelitian ini yaitu live shopping. Subjek penelitian ini penulis adalah penjual dan pembeli dari kegiatan live shopping, yaitu@jastipbynon, @jastipbynesha, @vrproject.id, @ ritanovianii dan@phebelay_. Objek penelitian ini berfokus pada proses live shopping Penulis menggunakan teknik pengambilan data dengan cara melakukan wawancara, observasi, studi pustaka, dan dokumentasi di penelitian ini.

\section{Hasil Temuan dan Diskusi}

Industri komunikasi digital telah berkembang pesat seiring perkembangan jaman. Begitu pula dengan kegiatan belanja khususnya belanja online. Masyarakat Indonesia kini menjadi lebih konsumtif belanja dengan menggunakan media online daripada berbelanja konvensional. (Harnina \& Juhaepa, 2018). Kegiatan belanja online umumnya dapat dilakukan melalui e-commerce (Bukalapak, Tokopedia, Lazada, Shopee, dan lain-lain) dan juga melalui media sosial (Instagram). Maraknya transaksi belanja online melahirkan suatu tren belanja online baru yang dinamakan live shopping. Kegiatan live shopping memiliki cara yang berbeda dengan belanja online kebanyakan. Kegiatan live shopping merupakan suatu kegiatan berbelanja secara online yang dilakukan secara langsung dan dalam durasi tertentu saja.

Kegiatan live shopping kerap kali dilakukan melalui media sosial Instagram. Dalam hal ini umumnya live shopping dengan memanfaatkan salah satu fitur Instagram yaitu Instagram Stories. Dengan menggunakan Instagram Stories akan memungkinkan pembeli untuk berinteraksi langsung dengan penjual. Dalam melakukan kegiatan live shopping, calon pembeli memiliki batas waktu tertentu sesuai yang telah ditetapkan oleh penjual dalam membeli produk yang dipasarkan.

Pembeli tidak dapat membeli produk yang telah melewati batas waktu yang telah ditentukan karena penjual sudah tidak di tempat. Dalam memasarkannya, penjual akan langsung mengunggah di tempat yang sudah ditentukan sehingga calon pembeli akan terasa sedang berbelanja di tempat si penjual berada. Hal ini yang membuat kegiatan live shopping berbeda yang lebih aktif dan interaktif dibandingkan kegiatan berbelanja online biasa. Selain itu barang yang dijual pada saat live shopping cenderung lebih banyak dan beragam.

Umumnya kegiatan live shopping biasa dilakukan di luar negeri seperti Singapura, Thailand, Malaysia, dan lain-lain. Hal ini dilakukan untuk membantu calon pembeli yang ingin berbelanja barang dari luar negeri secara mudah. Para calon pembeli biasanya mencari informasi mengenai kegiatan live shopping dari promosi orang-orang sekitar atau melalui fitur pencarian di Instagram dengan menuliskan keyword "live shopping" atau pencarian dengan menggunakan hashtag \#liveshopping. 
Salah satu fitur utama Instagram yang kerap kali digunakan dalam kegiatan live shopping adalah Instagram Stories. Fitur ini memungkinkan para penggunanya untuk mengunggah foto maupun video dengan kurun waktu ber-slide show dan dalam 24 jam saja.

Gambar 1. Kegiatan Live shopping Melalui Instagram Story

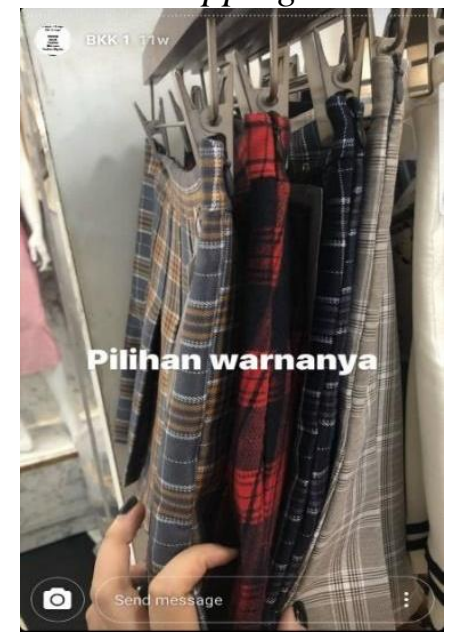

Sumber: Highlights Story akun @ jastipbynesha

Menurut www. finance.detik.com kegiatan live shopping menjadi tren dalam kegiatan belanja online di Instagram terbentuk, ada tren fenomena lain yang mendasari terbentuknya kegiatan live shopping yaitu kegiatan jasa titip atau yang lebih dikenal dengan jastip. Jastip merupakan peluang usaha yang dilakukan dengan cara membelikan suatu barang pesanan yang merupakan titipan oleh para pembeli. Awal mula terbentuknya kegiatan live shopping diawali dengan adanya kegiatan berlibur yang dilakukan khususnya ke luar negeri oleh para key informan dan karena banyaknya permintaan orang-orang sekitar untuk menitipkan barang-barang tertentu yang hanya ada di negara yang mereka kunjungi sehingga hal tersebut dijadikan sebagai peluang usaha baru dalam kegiatan berbelanja online yang dikenal dengan istilah jastip sebelum terbentuknya live shopping. Media sosial juga telah melahirkan bisnis baru, cara berdagang yang berbeda, bisa menjadi sumber penghasilan. (Rully \& Agus, 2017).

Setelah kegiatan jastip muncul lahirlah tren fenomena belanja online baru di Instagram yang dinamakan live shopping. Berbeda dengan jastip, kegiatan live shopping memiliki batas waktu tertentu dalam menjalankan transaksi jual beli dan berjalan lebih cepat. Terbentuknya kegiatan live shopping dalam kegiatan belanja online tentunya memiliki perbedaan tertentu bila dibandingkan dengan kegiatan belanja online biasanya. Salah satu key informan dalam penelitian ini, Vanesha Angelika menuturkan perbedaan dalam kegiatan live shopping dengan berbelanja online biasa terletak pada keberagaman barang yang dapat dijual.

Dalam kegiatan belanja online pada umumnya barang yang dijual biasanya lebih fokus dalam jenis yang sama. Lain dengan live shopping yang menawarkan berbagai barang yang ditawarkan sehingga lebih menarik. Selain keberagaman barang yang ditawarkan, live shopping juga dalam pelaksanaannya lebih menyenangkan karena dilakukan sambil jalan-jalan atau berliburan. Lain halnya dengan berbelanja online pada umumnya yang hanya membutuhkan handphone tanpa perlu bergerak dalam berjualan. 
Tabel 1. Model Live shopping

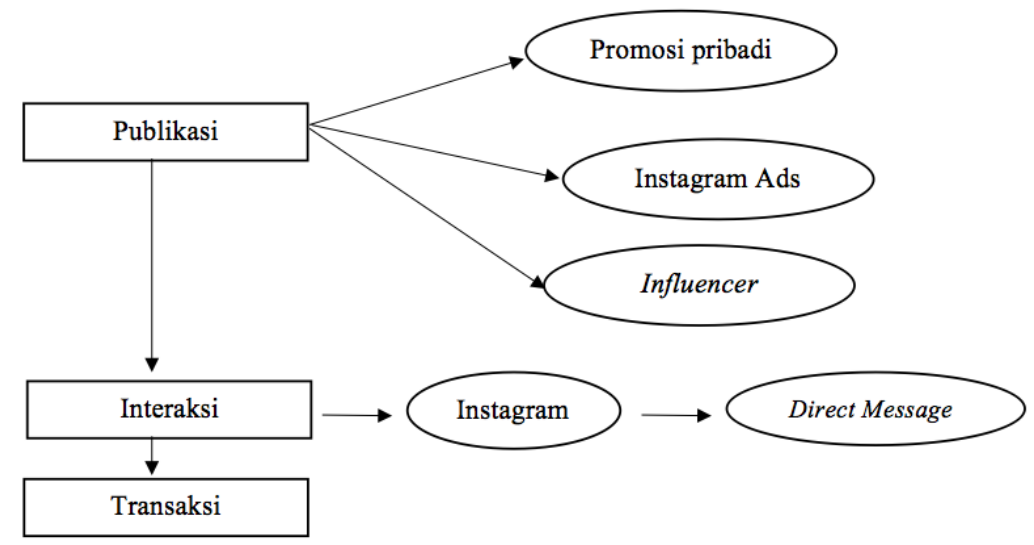

Publikasi merupakan suatu kegiatan yang dilakukan untuk menyebarkan informasi tertentu kepada masyarakat umum dengan berbagai cara yang variatif mulai dari buku, teks, gambar, konten audio visual dan website sehingga masyarakat menyerap informasi yang telah disebarkan untuk konsumen sehingga diharapkan kegiatan promosi dapat mempengaruhi masyarakat. (Astika, 2013: 28). Publikasi diharapkan dapat menarik calon pembeli yang tertarik untuk mengikuti kegiatan live shopping. Hal ini berkaitan dengan karakteristik media sosial yaitu sebagai media informasi kepada orang lain. (Van Dijk: 2013). Beberapa cara publikasi yang biasa dilakukan dapat melalui teman-teman atau lingkungan sekitar, fitur Instagram ads, dan melalui influencer. Instagram ads merupakan salah satu fitur yang diluncurkan Instagram pada 24 Oktober 2013. Dalam penggunaannya, Instagram ads menggunakan sistem targeting yang dapat memungkinkan para pengiklan untuk memperoleh informasi dan penargetan yang spesifik mulai dari usia, lokasi, jenis kelamin, ketertarikan, dan lain-lain.

Selain memanfaatkan fitur Instagram ads, para pelaku live shopping juga kerap kali melakukan publikasi melalui influencer. Bantuan publikasi ini biasa disebut endorsement. Menurut Sonwalkar et al, endorsement merupakan sebuah bentuk komunikasi yang dilakukan oleh seorang selebriti yang bertindak sebagai juru bicara yang mewakili suatu produk atau brand tertentu. Influencer merupakan orang yang dapat mempengaruhi keputusan pembelian menurut Kotler \& Keller $(2016,216)$.

Bentuk publikasi yang dilakukan melalui fitur Instagram ads dan influencer merupakan suatu bentuk komunikasi pemasaran yang dilakukan untuk menunjang usaha yang dilakukan. Jumlah pengikut yang banyak menyebabkan influencer banyak dilirik untuk mempromosikan produk pemilik usaha. Setelah melalui proses publikasi akan terjadi interaksi sosial antara penjual dan calon pembeli dalam kegiatan live shopping. Menurut Bonner, interaksi sosial merupakan suatu hubungan antara dua orang atau lebih individu, dimana kelakuan individu mempengaruhi, mengubah atau mempengaruhi individu lain atau sebaliknya (Gerungan, 2004: 62).

Interaksi dalam Instagram dapat dilakukan dengan memanfaatkan fitur direct message yang dapat langsung ditemukan apabila seseorang membalas Instagram Stories pihak lainnya. Fitur direct message merupakan fitur yang diluncurkan Instagram pada tahun Desember 2017 yang memungkinkan pengguna untuk mengirimkan pesan secara langsung kepada penerima pesan secara pribadi. Berkaitan dengan karakteristik media sosial yang dituturkan oleh Van Dijk (2013) yaitu interactivity atau interaksi. Hal ini memudahkan para penjual dalam live shopping 
untuk memberikan respon-respon tertentu dari calon pembeli karena kegiatan live shopping di Instagram memanfaatkan fitur Instagram Stories.

Gambar 2. Interaksi Melalui Direct Message

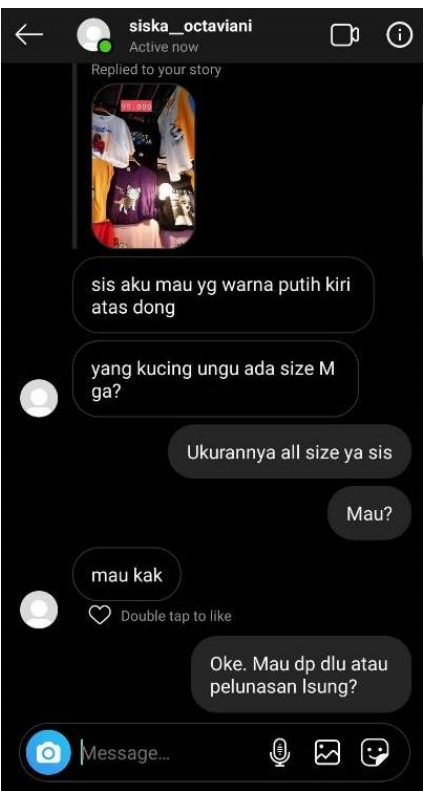

Sumber: Data Pribadi @ Vrproject.id

Setelah adanya interaksi yang terjadi penjual dan pembeli, tahap selanjutnya apabila adanya kecocokan dan kesepakatan yang sama maka transaksi akan berlangsung. Sistem pembayaran yang ditawarkan oleh penjual live shopping berbedabeda tergantung dari kebijakan masing-masing penjual. Salah satu key informan penulis yaitu Redita menerapkan sistem full payment dalam setiap transaksi yang ada untuk menghindari adanya penipuan yang dilakukan oleh pembeli yang akan merugikan. Proses menuju akhir yaitu saat deal cukup beragam karena tergantung dari tipe pembeli yang ada. Kisaran waktu proses deal berkisar antara 15 menit hingga 1 jam tergantung dari pembeli itu sendiri. Hal ini dipertegas oleh pernyataan salah satu key informan penulis. Kekuatan media sosial menjadi penting untuk membangun relasi dengan khalayak atau konsumen (Rulli, 2017).

Tabel 2. Perbandingan Data Key Informan

\begin{tabular}{|l|l|l|l|}
\hline No & \multicolumn{1}{|c|}{ Nama akun } & \multicolumn{1}{|c|}{ Banvaknva Live shopping } & \multicolumn{1}{c|}{ Pendapatan } \\
\hline 1 & ajastipbynon & 4 (empat) kali & 2 juta -7 juta \\
\hline 2 & ajastipbynesha & 10 (sepuluh) kali & 3 juta -8 juta \\
\hline 3 & avrproject.id & 4 (empat) kali & 9 juta -38 juta \\
\hline
\end{tabular}

Sumber: Dokumentasi Pribadi (2019)

Tabel 3. Perbandingan Data Informan

\begin{tabular}{|c|l|l|l|}
\hline No & \multicolumn{1}{|c|}{ Nama } & \multicolumn{1}{c|}{ Banyaknya Live shopping } & \multicolumn{1}{c|}{ Pengeluaran } \\
\hline 1 & Rita Noxiani & 7 (tujuh) kali & $200-300$ ribu \\
\hline 2 & Phebe Lay & 4 (empat) kali & $250-400$ ribu \\
\hline
\end{tabular}

Sumber: Dokumentasi Pribadi (2019) 


\section{Simpulan}

Berdasarkan hasil temuan dan analisis penulis dalam penelitian ini dapat disimpulkan bahwa kegiatan live shopping melalui Instagram merupakan bentuk kegiatan berbelanja online yang baru. Karena live shopping menawarkan kegiatan belanja online yang lebih interaktif dengan menggunakan fitur Instagram Story. Kegiatan live shopping dapat dianggap sebagai bentuk komunikasi pemasaran yang baru. Proses kegiatan ini diawali dengan melakukan publikasi melalui akun Instagram pribadi, promosi melalui Instagram Ads dan Influencer. Kegiatan live shopping dibandingkan berbelanja online biasa juga lebih menyenangkan karena live shopping bisa dilakukan sambil berjalan - jalan sehingga tidak membosankan dan menyenangkan. Jadi, 3 proses utama live shopping adalah promosi, interaksi, dan transaksi.

\section{Ucapan Terima Kasih}

Peneliti ingin mengucapkan banyak terima kasih kepada seluruh narasumber penulis yang telah memberikan informasi terkait dengan penelitian ini. Lalu kepada keluarga, sahabat, dan teman - teman penulis yang ikut menyemangati dan memberikan banyak dukungan dalam penulisan skripsi ini.

\section{Daftar Pustaka}

Cangara, Hafied. (2018). Pengantar Ilmu Komunikasi. Jakarta: PT RajaGrafindo Persada.

Dijk, Jan Van. (2013). The Network Society. London: SAGE Publication, Ltd.

Kotler, Philip \& Keller, Kevin Lane. (2016). Marketing Management, 15th Edition. England: Pearson Education.

Anwar, Rully Khairul \& Rusmana, Agus. (2017). Komunikasi Digital Berbentuk Media Sosial Dalam Meningkatkan Kompetensi Bagi Kepala, Pustakawan, dan Tenaga Pengelola Perpustakaan. Jurnal Aplikasi Ipteks Untuk Masyarakat, 205. Desember 15, 2019. Terarsip di: http://jurnal.unpad.ac.id/dharmakarya/article/download/14891/7918

Kulsia, C. E., \& Paramita, S. (2018). Analisis Akun Instagram Presiden Republik Indonesia Joko Widodo (@Jokowi) Dalam Membangun Reputasi Pada Masyarakat Virtual. Koneksi, 1(2), 303-309. https://doi.org/10.24912/KN.V1I2.1985

Rosliana, R., \& Loisa, R. (2019). Strategi Cyber Public Relatons dalam Memanfaatkan Media Sosial untuk Membangun Citra Perusahaan. Prologia, 2(2), 480. https://doi.org/10.24912/pr.v2i2.3733

Nasrullah, Rulli. (2017). Blogger dan Digital Word of Mouth: Getok Tular Digital Ala Blogger Dalam Komunikasi Pemasaran di Media Sosial. Jurnal Sosioteknologi Institut Teknologi Bandung, 2. November 23, 2019. : http://journals.itb.ac.id/index.php/sostek/article/view/3659/2489

Ridwan, Harnina., Masrul \& Juhaepa. (2018). Komunikasi Digital Pada Perubahan Budaya Masyarakat E-Commerce Dalam Pendekatan Jean Baudrillard. Jurnal Komunikasi, 100. November 20, 2019. Terarsip di: https://jurnalrisetkomunikasi.org/index.php/jrk/article/download/17/11/ 
Daniel, Wahyu. (2019, 11 3). Wow Transaksi E-commerce RI 2018 capai Rp 77 T Lompat 151\%. Retrieved August 21, 2019, from CNBC Indonesia. https://www.cnbcindonesia.com/tech/20190311101823-37-59800/wowtransaksi-e-commerce-ri-2018-capai-rp-77-t-lompat-151

Widowati, Hari. (2019, 25 4). Indonesia jadi negara dengan pertumbuhan ecommerce tercepat di dunia. Retrieved August 21, 2019, from Databoks. https://databoks.katadata.co.id/datapublish/2019/04/25/indonesia-jadi-negaradengan-pertumbuhan-e-commerce-tercepat-di-dunia

Rachman, Fadhly Fauzi. (2019, 3 3). Serba serbi bisnis jastip yang lagi ngetren. Retrieved November 18, 2019, from Detik. https://finance.detik.com/beritaekonomi-bisnis/d-4451410/serba-serbi-bisnis-jastip-yang-lagi-ngetren 